\title{
A microcosm approach to evaluate the degradation of tributyltin (TBT) by Aeromonas molluscorum Av27 in estuarine sediments
}

\author{
Andreia Cruz ${ }^{a, *}$, Isabel Henriques ${ }^{a}$, Ana C.A. Sousa ${ }^{a}$, Inês Baptista ${ }^{a}$, Adelaide Almeida ${ }^{a}$, \\ Shin Takahashi ${ }^{b}$, Shinsuke Tanabe ${ }^{b}$, António Correia ${ }^{a}$, Satoru Suzuki ${ }^{b}$, \\ Ana Maria Anselmo ${ }^{c}$, Sónia Mendo ${ }^{a}$ \\ ${ }^{a}$ Departamento de Biologia \& CESAM, Universidade de Aveiro, Campus Universitário de Santiago, 3810-193 Aveiro, Portugal \\ b Center for Marine Environmental Studies (CMES), Ehime University, Matsuyama 790-8577, Japan \\ ${ }^{\mathrm{c}}$ Laboratório Nacional de Energia e Geologia, Unidade de Bioenergia, Estrada da Portela, Bairro do Zambujal, Apartado 7586-Alfragide, \\ 2610-999 Amadora, Portugal
}

\section{A R T I C L E I N F O}

\section{Article history:}

Received 28 January 2014

Received in revised form

23 April 2014

Accepted 25 April 2014

Available online 21 May 2014

Keywords:

Tributyltin degradation

Aeromonas molluscorum Av27

Microcosm

Estuarine sediment

Bacterial community composition

\begin{abstract}
A B S T R A C T
Tributyltin (TBT) is a biocide extremely toxic to a wide range of organisms, which has been used for decades in antifouling paints. Despite its global ban in 2008, TBT is still a problem of great concern due to the high levels trapped in sediments. Aeromonas molluscorum Av27 is a TBT degrading bacterium that was isolated from an estuarine system. We investigated the ability and the role of this bacterium on TBT degradation in this estuarine system, using a microcosm approach in order to mimic environmental conditions. The experiment was established and followed for 150 days. Simultaneously, changes in the indigenous bacterial community structure were also investigated. The results revealed a maximum TBT degradation rate of $28 \%$ accompanied by the detection of the degradation products over time. Additionally, it was observed that TBT degradation was significantly enhanced by the presence of Av27. In addition a significantly higher TBT degradation occurred when the concentration of Av27 was higher. TBT degradation affected the bacterial community composition as revealed by the changes in the prevalence of Proteobacteria subdivisions, namely the increase of Deltaproteobacteria and the onset of Epsilonproteobacteria. However, the addition of Av27 strain did not affect the dominant phylotypes. Total bacterial number, bacterial biomass productivity, 16S rRNA gene and denaturing gradient gel electrophoresis (DGGE) analyses also indicated alterations on the bacterial community structure over time, with bacteria non-tolerant to pollutants increasing their representativeness, as, for instance, the increase of the number of Alphaproteobacteria clones from $6 \%$ in the beginning to $12 \%$ at the end of the experiment. The work herein presented confirms the potential of Av27 strain to be used in the decontamination of TBT-polluted environments.
\end{abstract}

(c) 2014 Elsevier Inc. All rights reserved.

\section{Introduction}

Tributyltin (TBT) is one of the most toxic substances ever deliberately introduced into the marine environment (Evans et al., 2000; Fent, 1996; Goldberg, 1986). It has been applied in the preservation of wood, textiles and paper to prevent degradation of the materials (Bennett, 1996). Additionally, TBT has been widely used as the active ingredient in antifouling paints used in boats and ship hulls to avoid bioincrustation, therefore

\footnotetext{
* Correspondence to: Departamento de Biologia, Universidade de Aveiro, Campus Universitário de Santiago, 3810-193 Aveiro, Portugal. Fax: + 351234372587.

E-mail address: andreia.cruz@ua.pt (A.Cruz).
}

constituting an important contaminant in aquatic environments (Antizar-Ladislao, 2008; De Mora, 1996; Yebra et al., 2004).

The high toxicity of TBT has resulted in numerous and widespread adverse biological effects to a wide range of organisms, from bacteria to mammals and from the molecular to the community level (Cruz, 2012; Galante-Oliveira, 2010). One of the most deleterious effects of TBT is imposex, a phenomenon characterized by the superimposition of male sexual characteristics on female gastropods (Smith, 1971). Another examples are the negative effect on growth and metabolism of bacterial cells (Cruz et al., 2012), the induction of embryos malformations (Antizar-Ladislao, 2008) and the induction of adipose tissue differentiation and obesity in mammals (Ohtaki et al., 2007).

These adverse effects alongside with its persistence and widespread distribution in the aquatic environment lead to the 